\title{
8
}

\section{Public financial management and the campaign against extravagant position-related consumption in China}

\author{
Hanyu Xiao ${ }^{1}$
}

\section{Introduction}

China has been plagued by pervasive corruption in multiple and complex forms since the 1980s, and especially in recent years, posing a serious challenge to governance and the government's legitimacy. Among various forms of corruption and misconduct, extravagant positionrelated consumption (san gong xiao fei in Chinese) attracts the general public's attention, generating a widespread belief that position-related consumption is closely related to corruption and misconduct among officials. Such extravagant consumption, if not effectively controlled, may affect the public's trust in the government and its legitimacy. Accordingly, President Xi Jinping, with his colleague Wang Qishang, the General Secretary of the Central Discipline Inspection Commission (CDIC), launched an anti-extravagance campaign in late 2012.

1 An early version of this chapter was presented at the Fifth Greater China-Australia Dialogue held at National Taiwan University in November 2015. I am grateful to Professor Andrew Podger, Professor Hon S. Chan and other participants for their comments. 
This study does not aim to examine the current campaign comprehensively. Instead, it argues that the campaign has provided a unique opportunity to examine the dynamics and effectiveness of an anticorruption process, and it may provide solid evidence-based policy suggestions for decision-makers. The lack of an evidence base to date seems clear. Over the past three decades, the Chinese Government has made intensive endeavours to fight against official extravagance, so the reoccurrence of anti-extravagance campaigns itself indicates the ineffectiveness of the pre-2012 efforts. The current campaign has achieved an effective shortterm goal: seriously disciplining government officials who violate rules and regulations. According to the monthly reports from the CDIC (2016b), 81,049 government officials were reported and sanctioned for violation of rules against extravagant position-related consumption by May 2016. The revenue of high-end restaurants and sales of luxury wine have also dropped dramatically since the current anti-extravagance campaign began. Nevertheless, extravagant position-related consumption seems to continue, with about 3,000 government officials reported and sanctioned every month (CDIC 2016a). More importantly, it is apparent that the institutional incentives that lead to extravagant position-related consumption largely remain in place, which casts doubt on the long-term effectiveness of this latest campaign (Gong and Xiao 2017).

This chapter explores the persistence of extravagant position-related consumption by emphasising the role of formal and informal rules as well as their interactions and focusing on public financial management (PFM). Over the past two decades, the government has strengthened its financial management framework. This includes the formation of formal financial rules to regulate governmental activities. As a result, corruption related to public money has been reduced over the past decade. However, the growth of formal rules does not necessarily lead to a decline in the role of informal rules within the public sector. The informal rules evolve and continue to play a significant role in influencing position-related consumption. The empirical analysis identifies three forms of interactions where informal rules override formal ones.

Empirical evidence for this research consists of three sources. First, 65 interviews were conducted at different administrative levels in different cities, including Beijing, Shanghai, Guangzhou, Zhanjiang and Changsha, from 2012 to $2014 .^{2}$ Second, more than 150 official documents on

2 For details of the interviewees' information (such as administrative levels, posts and organisation types), refer to Gong and Xiao (2017). 
position-related consumption were collected. As demonstrated below, this study analyses the content of these rules and regulations to understand how the government fights official extravagance. Finally, this research is supported by media reports. Collecting data from these different sources helps to ensure the validity of the empirical evidence and reduces any potential bias.

The next section introduces the concept of position-related consumption. This is followed by a discussion of the theoretical concepts behind the forces that guide position-related consumption-the formal and informal rules. Section four discusses how the rules of PFM have developed to regulate position-related consumption. Section five goes a step further to analyse how informal rules override formal financial rules and lead to extravagant position-related consumption, and the final section discusses the theoretical and practical implications.

\section{Position-related consumption in China}

Position-related consumption in China manifests itself in three forms of public expenditure (sangong zhichu): official hospitality, government vehicles and official trips. According to the Ministry of Finance (MoF 2012: 224):

[The] three public expenditures, which are included in the centrallevel budgeting and auditing management [yujuesuan guanli], refer to expenditures on official overseas trips; the purchase, operation and maintenance of government vehicles; and official hospitality.

Several points should be elaborated. First, the actual spending items of position-related consumption are more complex than they appear. For example, official hospitality consists of all kinds of official banquets, accommodation and other expenditure (such as conference costs and transportation fares). Second, the government lacks accurate information about the magnitude of position-related consumption because such consumption happens in all government organisations and each unit holds the actual consumption information. Third, the government defines only official activities funded by budgetary appropriation (caizheng bokuan) as position-related consumption, whereas similar consumption supported by small amounts of off-budget revenue held in separate accounts or made by non-budget funded organisations such as state-owned enterprises (SOEs) is not recognised in the official definition. 
As distinct from the official definition, this study defines position-related consumption as public expenditure on official hospitality, government vehicles and official trips (both overseas and domestic) regardless of funding sources. This definition is broader than the official one because all relevant activities involving government officials as recipients are considered as positionrelated consumption. For example, lavish official banquets for superiors provided by other government departments are seen as position-related consumption, although the spending is not reimbursed in the superior department. Public service units and SOEs other than government departments also experience position-related consumption because they either receive public money from the government or are affiliated with and supervised by the government.

Admittedly, position-related consumption is necessary for the daily operation of government departments. However, few countries have position-related consumption as lavish as China. Extravagant positionrelated consumption has been widely discussed by the public and Chinese scholars. First, the overall magnitude of position-related consumption is extremely high. Second, Chinese people widely believe that lavish position-related consumption is a form of corruption. Finally, lavish consumption is a nationwide phenomenon rather than a local practice confined to a few regions. Those in both rich eastern and poor middle and western regions have been found to consume lavishly.

The Chinese central government has intensified its efforts to curb and stop lavish position-related consumption since the 1980s. The central government or central-level departments stipulated over 150 official circulars during this period, among which three types of efforts can be identified. The first is ad hoc policy, which is a short-term response to lavish position-related consumption, especially when the problem catches the attention of central authorities. Ad hoc policies include special rectifications that target a particular phenomenon and official circulars that reiterate the disciplinary rules with which government officials must comply. Second, the central government has made intensive efforts to establish legal rules and guidelines through various official circulars and provisions. Compared with ad hoc policies, this type of measure usually adopts a long-term perspective and seeks to provide basic behavioural guidelines for government officials. Formal regulations are usually derived from provisional regulations following several years of trial and error. Finally, the government employs various fiscal instruments to regulate and control extravagant position-related consumption. Section four will discuss this in detail. 
Nevertheless, extravagant consumption continues. Regarding official banquets, an often-cited estimation offered by a scholar from the Central Party School in 2006 suggested that the annual expenditure on official banquets had reached RMB200 billion (A $\$ 38$ billion) (Study Times 2004). In 2012, the People's Daily, the mouthpiece of the central authorities, reported that hundreds of billions of dollars of public money were spent annually on official hospitality, and that this expenditure made up two- or three-tenths of the administrative fund (xingzheng jinfei) (People's Daily 2012). Reports on the attitude of the public towards lavish official hospitality also echo the likely scale of the problem. Based on an online survey of 10,844 people in early 2012, China Youth Daily found that 85.5 per cent perceived official hospitality as a very serious phenomenon and 63.8 per cent of the respondents were concerned about the reforms. Regarding the effectiveness of official circulars in reducing lavish hospitality, only 22.2 per cent of the respondents believed that these measures were 'very good', while 40.6 per cent thought they were ineffective (China Youth Daily 2012). Another online survey, in 2011, involving 10,275 respondents, revealed more striking results: as many as 99.1 per cent of the respondents considered official hospitality expenditure a serious phenomenon (China Economic Times 2011).

Evidence shows that government vehicles are still being mismanaged and misused to this day, including both their purchase and their use. Purchases need to be analysed in terms of two factors: who is eligible to purchase a vehicle and the price of the vehicle. Although some rules specify that only officials at or above the deputy ministerial/provincial level can purchase designated government vehicles, many low-ranking officials are using such vehicles. In fact, one deputy chief of a district department advised that even the officials at the section level (keji ganbu) could have designated vehicles. ${ }^{3}$ Former governor of Guangdong province Huang Huahua held a similar view:

We have too many government vehicles. In the old days, only those officials at or above deputy-provincial level could be given designated government vehicles. Nowadays, even the chiefs of units [gu zhang $]^{4}$ may have their own government vehicles. (Yin 2011: 25)

3 Interview with an official at the district level, Shenzhen, May 2012.

4 The unit chief is the lowest administrative rank within the bureaucratic system. 
In addition, the prices paid for government vehicles were often far beyond the price spectrum set by the rules and regulations, thus contributing to excessive expenditure in this area. According to a news report, one SOE spent as much as RMB9.21 million (A $\$ 1.8$ million) to purchase 16 vehicles, indicating the average cost of each vehicle was RMB576,000 (A \$110,000) (Guangzhou Daily 2011)_far beyond the allowable purchase price set by the central government. Most strikingly, the party secretary of one very poor county (based on its gross domestic product [GDP] per capita) used a government vehicle valued at more than RMB1 million (A\$190,000) (China News Service 2013). The rules and regulations for monitoring and controlling the number and price ceiling of government vehicles have thus often failed and work only on paper.

As a result, extravagance was found in the management of government vehicles. There were approximately four million government vehicles in 2004, with a total annual cost of RMB408.5 billion (A $\$ 77.8$ billion), which accounted for 13 per cent of the fiscal revenue for that year (Study Times 2004). A proposal submitted by a representative of the national congress estimated that the government had approximately 3.5 million vehicles in the mid-1990s, and spent about RMB300 billion (A\$57 billion) every year (Nanfang Metropolis Daily 2003). Although the aforementioned figures are estimates, they suggest that the amount of money wasted on government vehicles is sizeable and the management of government vehicles has largely been ineffective.

Finally, expenditure on official trips has been considerable in recent years. An often-cited estimation reported that the expenditure on overseas trips reached RMB300 billion (A $\$ 57$ billion) in 1999. ${ }^{5}$ Another source reported that overseas trips cost RMB200 billion (A $\$ 38$ billion) in 2004 (People.com 2005). These estimations are of a similar order to those for spending on official hospitality and government vehicles. The former president of Xinhua News Agency Tian Congming expressed the view that spending on overseas trips remained rampant because of a loophole in off-budget revenue (Beijing News 2012).

5 For more details, see Phoenix (2013); Study Times (2004). 


\section{A theoretical concept}

The existing literature has provided several perspectives with which to understand extravagant position-related consumption. Various scholars argue that extravagance is caused by Chinese culture (or mianzi) (Ho 1976; Guo 2010), the greed of individual government officials (Cope 2000; Hindmoor 2006) or poor policy implementation (Dong et al. 2014). ${ }^{6}$ These perspectives provide useful insights for explaining extravagant position-related consumption. Yet, few studies have explored the process, dynamics and mechanisms of such consumption and how different rules and values interact with one another in this area.

This chapter argues that a PFM perspective provides an opportunity to investigate the dynamics of extravagant consumption, for the following reasons. PFM plays a key role in good governance because it 'stands at the heart of resource management in all governments and has broad influence on the ability of government to provide services, manage transparently, and ensure stability' (Andrews 2010: 11). Conducting an interim assessment, $\mathrm{Ma}$ and $\mathrm{Ni}$ (2008) find that a control-oriented reform of the budget system in China has reduced fund misuse at local levels. An effective financial management system is also vital for the control of position-related consumption because, essentially, all such consumption involves public money.

Currently, Gong and Xiao (2017) employ institutional isomorphism theory to explain why extravagant position-related consumption has circumvented the government's anti-extravagance endeavours over the past three decades. According to this study, extravagant position-related consumption is embedded in the Chinese bureaucracy and driven by substantial institutional incentives: vertical, horizontal and normative pressures. However, their study does not pay sufficient attention to particular rules and regulations of PFM. This chapter will focus on PFM, employing institutional analysis and drawing on the literature on formal and informal rules as well as their interactions.

Scholars have long emphasised the role of rules and regulations in understanding the behaviour of individuals, organisations and societies (North 1990; Knight 1992; Greenwood and Hinings 1996; Hall and

6 For more detailed discussion, refer to Gong and Xiao (2017). 
Taylor 1996). There are two types of rules: formal and informal. While formal rules are generally officially written and endorsed by the formal power governing organisations, informal rules are often thought to be socially shared, unwritten and enforced outside the official power of organisations (Helmke and Levitsky 2004).

The existing literature has examined various organisational phenomena from the perspective of formal and informal rules. Dittmer (1995) argues that informal politics is an important way to understand real politics in contemporary China. Tsai and Dean (2015) examine the mishu system in authoritarian China, which has influence and power beyond the formal rules. ${ }^{7}$ Similarly, Liu and Lin (2014) find intensive interactions between formal and informal rules when they investigate the decision-making process for a project earmarked for enterprise listing involving different departments in a Chinese province. Following the approach of these studies, this chapter identifies the formal and informal rules affecting position-related consumption and examines how their interactions lead to extravagant consumption.

The next section explores how the PFM framework regulates positionrelated consumption.

\section{Attempts to strengthen public financial management}

Since the 1990s, China's central government has been strengthening the PFM framework, which is helpful for controlling lavish position-related consumption. In recent years, the Chinese Government has introduced several important budget reforms to tighten the control of public money.

7 The mishu (secretary) system in China consists of institutional mishu and personal mishusupport staff employed mainly in party committee general offices. Since mishu work closely with leading cadres and are involved in the decision-making and implementation processes, they often have higher informal power than their formal positions and levels suggest. 


\section{Development of public financial management in China}

First, laws and regulations pertaining to PFM have been introduced and updated. China's Budget Law, government accounting law and auditing regulations (shenji tiaoli) took effect from the 1980s, providing basic guidelines for PFM. Second, budget reforms have been introduced since the 1990s. Departmental budget reform demands that government departments include all revenue and expenditure when compiling departmental budgets. A centralised treasury management system and a centralised procurement system were introduced as well, replacing the old decentralised management methods in respective fiscal areas (Ma 2009). According to recent studies, budget reforms since 1999 have increased budget control capacity and reduced fiscal misconduct (Ma and Ni 2008; Ma 2009).

Third, the central government gradually increased its control and management of revenue and expenditures. The Chinese fiscal system has traditionally consisted of official budgets, extra-budgets and even illegal money (Wedeman 2000). While rules and regulations for official budgets were comprehensive, the use of extra budgets and illegal money was rife among local governments. Such activity periodically becomes public and the central government has to take action against it. An important initiative has been separating revenue and spending (shouzhi liangtiaoxian). For example, a circular promulgated by the General Office of the State Council (2001) requires departments to include all extra-budget revenue in their official budget and to hand over all revenue to the government. The central government has also moved to rectify the malpractice regarding small off-budget accounts in recent years. With weak regulation from superiors, small off-budget accounts often led to malpractice and became a major source of lavish position-related consumption.

To sum up, China has made great endeavours to strengthen its PFM and establish a control-oriented fiscal system.

\section{Detailed financial regulations on position-related consumption}

The central government has introduced various fiscal methods to regulate position-related consumption. More than 67 circulars relevant to the PFM of position-related consumption have been issued over the 
past three decades. These circulars cover all the important components of position-related consumption-namely, the cost of domestic and overseas trips, official hospitality and government vehicles. The central government has issued as many as 10 circulars focusing on official trips (domestic and overseas) in recent years. Four specify major expenditure items pertaining to domestic trips, including accommodation, intra- and inter-city transportation fares and meal subsidies. The MoF has adopted lump-sum management for these expenditure items for officials below the level of division chief (si zhang), indicating that fixed standards are applied to these items. In 2006, the MoF also identified designated hotels and restaurants that should be used to enhance the management of official meetings and domestic trips. In particular, government officials who make a local visit have to stay at hotels on the official list and the sites for official meetings should be chosen from the list of designated restaurants $(\mathrm{MoF}$ 2006). Six circulars have been issued regulating overseas trips, according to which expenditure consists of costs for international travel, inter-city transportation, accommodation, meal subsidies and minor charges (zafei). The central government makes clear the required standards for these items and updates these standards according to price changes in the market. The MoF has also required improvements to the financial management of overseas trips with respect to budgeting plans, verification of relevant receipts and audit and investigation. A circular issued in 2013 requires that relevant central departments inspect the details of official overseas trips in either a regular or a more random manner $(\mathrm{MoF}$ and Ministry of Foreign Affairs 2013).

Two circulars focus on particular aspects of official hospitality (General Office of the CCPCC and General Office of the State Council 1994a; MoF 1998). The 1994 circular emphasised that, when central government officials visit, the accommodation and banquet standards should not exceed the rates set for local governments. The MoF in 1998 issued the Regulations of the Fiscal Management of Official Hospitality Items in Administrative Organs and Public Service Units (xingzheng shiyu danwei yuwu zhaodaifei liezhi guanli guiding) (MoF 1998), which remain the most important fiscal guidelines for official hospitality. This guideline specifies the maximum share of official reception costs in departmental operation costs (gongwu feiyong), with 2 per cent for local government entities and 1 per cent for central government departments. 
Regarding the financial management of government vehicles, the Fiscal Management Methods of Budget and Final Reports of Government Vehicles in the Party and Government Organs (dangzheng jiguan gongwuyongche yusuan juesuan guanli banfa) was promulgated in 2011 (MoF 2011). This circular was the first decree authorised by central authorities targeting the fiscal management of government vehicles. This measure was also an extension of the Regulations on the Purchase and Use of Government Vehicles in the Party and Government Organs (General Office of the CCPCC and General Office of the State Council 1994b). The 2011 measure included the administrative procedures for managing government vehicles, the identification in budgets of vehicle purchase and operational costs, the implementation process for purchasing vehicles and the compilation of final reports on the purchase and use of vehicles.

In addition to these circulars specifically concerning position-related consumption, others have been introduced to regulate activities that may breed extravagant spending. Two main efforts have been made in recent years. First, the central government has sought to disclose budgetary information to the public. The 'Regulations on Opening Government Information', which took effect in May 2008, require the government to disclose governmental information to the public. Later, information about position-related consumption was required, including detailed explanations (General Office of the State Council 2012). Second, the State Council has frozen budgets for position-related consumption since the 2010 fiscal year. This followed the MoF and the National Audit Office (NAO) jointly promulgating a circular in 2009 calling for a reduction in expenditure on position-related consumption. Specifically, departmental budgets for official overseas trips were limited to 80 per cent of the average spending over the previous three-year period (2006-08). The spending on government vehicles was limited to 85 per cent of the respective average, while the cost of official receptions was required to be reduced by 10 per cent below that of 2008 (MoF and NAO 2009).

To conclude, the central government has made intensive efforts and has established strict fiscal management measures trying to curb extravagant position-related consumption. There would be few opportunities for lavish consumption if the government strictly followed these financial rules. The next section analyses how government officials circumvent the formal financial rules and why extravagant consumption continues. 


\section{How do informal rules circumvent formal rules of financial management?}

This section examines how government officials sidestep the formal financial rules and consume lavishly. There are several types of circumstances by which informal rules circumvent the formal ones.

\section{Informal rules promoting organisational interests override formal financial rules}

When informal rules are closely tied to organisational interest, formal financial rules often become weak in regulating consumption. Government organisations often emphasise their own organisational interests at the cost of other socially desirable goals; in other words, some activities may enrich the organisation at the cost of a whole sector or society. Lu (2000: 275) revealed that a common pattern of corruption in the Chinese Government is 'organisational corruption', which is departmentbased and conducted in the name of an official unit.

A closer analysis of lavish consumption reveals that organisational interest is considered the most important rationale for government officials to try to ethically justify governmental malpractice. Even though engaging in lavish consumption may bring ethical anxiety for government officials, especially those who tend to follow the formal rules, moral concerns would be significantly reduced if such behaviour was justified in the name of organisational interests:

In many cases, good official hospitality arrangements for upper officials can yield organizational benefits. The provincial governor approached Beijing to obtain approval for the large programs for the province ... The governor was personally reluctant to participate in drinking and dining because it is not helpful and healthy for him. However, the governor had to offer extravagant hospitality because he must get approval from Beijing so he could begin implementing his projects in the province. ${ }^{8}$

In reality, our work entails official hospitality. For the problems that cannot be solved on the table, we can easily tackle them in private places (in restaurants for official hospitality). To be honest, none of us is willing

8 Interview with the departmental official of a provincial Beijing liaison office, Beijing, May 2013. 
to eat and drink in that manner. In fact, I prefer to eat at home after work. Official hospitality is exhausting. However, such hospitality is part of our work, and we cannot escape from it. ${ }^{9}$

In the fieldwork for this chapter, many other interviewees presented the author with similar views. Organisational interest became the main reason for lavish consumption. In this situation, government officials usually follow the informal practice — engaging in lavish consumption-because they envisage that it will yield higher organisational benefits. Therefore, following the financial rules pertaining to position-related consumption becomes less important.

\section{'Invite' other government departments to pay for the consumption}

It is nonetheless risky to explicitly violate the formal rules and consume lavishly, especially when the government has launched such a severe anticorruption campaign. An alternative is to mobilise additional sources of funds while the government departments initiating the consumption still follow the formal rules. It is common for upper-level government departments to 'invite' lower-level ones to pay for their additional position-related expenditure. Therefore, such expenditure does not appear in the accounts of the upper-level departments. The following interviews demonstrate how officials respond to the strict formal rules:

If a bureau has limited money, then it is reasonable to purchase government vehicles by forced apportionment funds collected from other units. Otherwise, the bureau should find someone who can offer financial support. ${ }^{10}$

It is hard to imagine that I cannot use government vehicles. I will immediately call someone and borrow a vehicle in that case. ${ }^{11}$

Forced apportionment funds possibly exist for overseas trips. Upper governments sometimes assign travel expenses to our bureau when they cannot assign them to their own departments. ${ }^{12}$

Official trips also have forced apportionment of funds. For instance, senior officials from the People's Congress or the People's Political Consultative Committee in my county have few things to do. To kill time,

9 Interview with a departmental official, Guangzhou, July 2012.

10 Interview with the deputy chief of a county bureau, Zhanjiang, July 2013.

11 Interview with the deputy chief of a county bureau, Zhanjiang, July 2013.

12 Interview with an official in a district finance bureau, Guangzhou, July 2012. 
they sometimes call me and demand that I accompany them to conduct fieldwork in local places. For me, this 'invitation' means that I should pay part of the travel costs. They may have the travel budget from the Bureau of Finance. Generally speaking, an official trip costs RMB3,000 [A \$570], but my bureau often pays RMB5,000 [A \$950] for the trip. ${ }^{13}$

The above evidence demonstrates that forced apportionment is often used by upper-level units to shift additional consumption. This finding is also supported by the NAO's report. The NAO launched an audit of 58 central departments in 2013 and the results revealed that, among these departments, 31 (or 53.4 per cent) had forced apportionment pertaining to lavish consumption to lower-level departments or units. The total amount of forced apportionment was more than RMB34.7 million (A \$6.6 million). ${ }^{14}$ The forced apportionment related to two forms of lavish consumption, the first of which were overseas trips. In many cases, central government departments demanded subordinate units cover their costs on overseas trips, while sometimes subordinates actively provided funds to support the overseas trips of their supervisors. Among 58 central departments, 18 were found to have conducted forced apportionment for overseas trips. Second, some lavish consumption was reimbursed under the name of conference expenditure by subordinate units. Audit reports showed that 22 ministries apportioned conference expenditures to other units, including affiliated units, subordinates and other organisations (qita danwei). ${ }^{15}$ Nine ministries had forced apportionment on both official conferences and overseas trips.

\section{Manipulating the auditing}

When the first two options are not available, government officials may seek to hide extravagant consumption by colluding with auditors and accountants within the government department. Accountants in the public sector must obey the financial rules and monitor possible financial flaws, thereby securing the proper spending of public money. By contrast, fieldwork by the author indicates that, in reality, public accountants' first priority was to follow the instructions of departmental leaders, regardless of their professional values and formal rules. The following interview was illustrative:

13 Interview with the deputy chief of a county bureau, Zhanjiang, July 2013.

14 This figure is based on the author's calculations. In some cases, accurate figures related to this malpractice were not given in audit reports.

15 No further explanation on other organisations exists in official reports; however, those organisations are usually subject to the supervision of ministries. 
Our accountants are supposed to serve the department. However, they mainly serve the leaders. Although there are professional guidelines for their work, they have to obey the instructions of the leaders in the first place. Why? If you refuse to follow the leaders because their directions violate professional rules, then the leaders will fire you immediately. ${ }^{16}$

Although departmental leaders may not dare to ask the accountants directly to engage in corruption, leaders could ask them to hide some extravagant position-related expenditure in departmental accounts. Another interviewee from a district-level department told this story:

Now it is demanded that departments should disclose their positionrelated consumption to the public. We will submit the 'real expenditures' to the department head for their approval before the disclosure. Since the real expenditures are very high, it is impossible to disclose them to the public. Therefore, before the disclosure, accountants have to revise the information so that it seems to follow the fiscal rules. ${ }^{17}$

The above evidence indicates that accountants within government departments play a very weak role in correcting fiscal flaws. They believe they have to follow their leaders' instructions.

In addition, PFM focuses only on activities funded by public money, while much position-related consumption is supported by small offbudget accounts that are subject to weak financial rules. Simply put, the accounting system does not provide comprehensive guidelines to clearly identify specific position-related consumption items. The blurred definition of position-related consumption has resulted in high levels of discretion for government departments, allowing them to easily hide such consumption. For example, the definition of an official banquet by the local audit office was problematic:

The audit office only recognises the expenditure as official hospitality with banquet receipts, which is ridiculous. In this case, we do not go to restaurants that can only issue banquet receipts. Instead, we go to restaurants that can offer meeting receipts. Nowadays, we are making a list of restaurants that cannot provide meeting receipts, so that we won't go there anymore. ${ }^{18}$

To escape auditing, government departments hide real expenditure on official banquets under meeting expenditure.

16 Interview with the deputy chief of a county bureau, Zhanjiang, July 2012.

17 Interview with an official in a district finance bureau, Guangzhou, July 2012.

18 Interview with a departmental official, Guangzhou, July 2012. 


\section{Do formal financial rules go too far and inadvertently foster informal rules?}

According to the fieldwork, financial rules dominated by frugality may have inadvertently generated incentives for government officials to consume lavishly. The standards set for consumption items may sometimes be too low for government officials to fulfil their official duties. In other words, the central government emphasises frugality too much and does not adjust spending ceilings for position-related consumption sufficiently or in a timely way:

The spending standard for domestic official trips is believed to be too low [such] that government officials who pay a local visit could not arrive [at] the destination at all, if officials strictly follow the train fare standard. However, all officials make it. ${ }^{19}$

This quotation illustrates that the reimbursement allowed for domestic trips is too low. Thus, government officials have to evade fiscal rules. Other interviewees have similar views. An official who works at a provincial department told the author:

Government officials should not stay in cheap chain hotels for domestic official trips. These hotels are not appropriate for officials. We have to find more comfortable restaurants. However, rules and regulations do not allow us to do that. ${ }^{20}$

Low salaries for government officials at the local level may also be an important cause of lavish position-related consumption. The effectiveness of PFM entails some necessary conditions, including competitive salaries for government officials. Studies have revealed that government officials are more prone to corruption if their salaries are low (Wu 2014). This may hold true for lavish position-related consumption. Government officials with lower salaries may have higher incentives to engage in lavish positionrelated consumption. Several government officials complained about their low salaries when they talked about position-related consumption. ${ }^{21}$

19 Interview with a senior official of the MoF, Beijing, May 2013.

20 Interview with an official in a provincial office, Changsha, March 2014.

21 Interview with a departmental official, Guangzhou, July 2012; interview with an official in a provincial office, Changsha, March 2014. 
The problems with formal financial rules have therefore provided opportunities for government officials to think about violating these specific rules about position-related consumption.

\section{Discussion and conclusion}

The above analysis focuses on consumption before 2012. Given the notable effects of the current anti-extravagance campaign, it is worthwhile discussing position-related consumption since 2012 in more detail. The current campaign was launched in late 2012, starting with the enforcement of an official circular-the 'Eight Regulations'-by the Chinese Communist Party (CCP) on 4 December. The new regulation tightened control over official extravagance and bureaucracy. Several ad hoc circulars were issued immediately after the start of the campaign. The CDIC, for example, issued circulars in 2013 to ban New Year's cards and New Year shopping using public money (CDIC 2013), gift-giving during the Mid-Autumn Festival and on National Day (CDIC and The Mass Line Education Small Leading Group 2013a) and forbidding government officials from participating in private club activities (bui suo) (CDIC and The Mass Line Education Small Leading Group 2013b). The central government issued long-term guidelines providing detailed instructions in line with the 'Eight Regulations'. In October 2013, the CCP and the State Council jointly stipulated the 'Regulations on Guiding the Party and Government Organs in Practising Frugality and Rejecting Extravagance'. This circular tightened the management of expenditure on management, overseas and domestic trips, official hospitality, government vehicles, official conferences, use of official houses and resource saving. The CDIC promptly prioritised the reduction of lavish official extravagance, which was the first time it had taken severe disciplinary action over official extravagance. The discipline inspection system increasingly mobilised resources to detect and penalise behaviour that violated the guidelines in the Eight Regulations. Wang Qishang said the implementation of the Eight Regulations should be reported to the Nineteenth CCP National Congress (People.com 2014), which indicates that the enforcement of the Eight Regulations was an important agenda item for the CDIC at least until 2017. 
The sanction against government officials who violate the Eight Regulations was increasingly severe: they were demoted or dismissed. A provincial official noted that a deputy minister was demoted because he was caught receiving lavish official hospitality in a locality. ${ }^{22}$ This sanction was particularly heavy, given that few officials at such an administrative rank have been demoted for such activity.

The current anti-extravagance campaign has yielded mixed results. On the one hand, evidence shows it has had a significant effect on the level of spending on official hospitality. In early 2014, the chief executive officer of the New Century Tourism Group (kaiyuan lvye jituan), which has more than 40 five-star restaurants, said the average turnover of its catering sector was reduced by 20 per cent in 2013 and revenue from catering and conferences dramatically decreased (Xinhua 2014). Government officials also commented that they seldom hosted guests in high-end restaurants since the current campaign began and superiors at high levels refused official banquets offered by low-level officials. ${ }^{23}$

On the other hand, more complex forms of lavish position-related consumption were reported. Malfeasance was organised in the name of plausible activities, such as inviting superiors to luxurious food tasting events, whereas others held luxurious banquets at remote or hidden places (Wangyi 2013). One report observed that the enforcement of the Eight Regulations led to the emergence of private clubs and internal canteens, which were difficult to detect. ${ }^{24}$ As high-end restaurants are no longer 'safe' for government officials, private clubs, nongjiale ${ }^{25}$ and internal canteens are more popular for lavish banquets.

The following interviewee explained how local officials responded passively to the current anti-extravagance campaign:

22 Interview with the chief of the general office of a provincial department, Changsha, March 2014.

23 Interviews with several officials of a prefectural discipline inspection commission, Zhuhai, May 2014.

24 For more details, see Nanjing Daily (2013); Beijing News (2014).

25 Nongjiale is a Chinese version of rural tourism and it literally means 'delights in farm guesthouses'. Government officials like to use nongjiale as a way to have lavish official banquets because it is difficult to detect. 
Officials now dare not consume luxuriously since the Eight Regulations. However, the crux is not solved. Everyone now behaves in a low-key manner, being quiet and waiting. The problem remains. Officials now passively respond to the directives of the central government. How to solve the crux remains an open question. ${ }^{26}$

In spite of the significant achievements of the campaign, eliminating official extravagance will be a protracted war. According to Helmke and Levitsky (2004), the interaction between formal and informal rules has two dimensions: convergent/divergent outcomes and effective/ineffective formal rules. Convergent outcomes indicate that informal rules produce similar results to those of the formal ones; otherwise, the outcome is divergent. The second dimension considers the effectiveness of formal rules. Table 8.1 summarises these four types of interactions between formal and informal rules. According to Helmke and Levitsky's (2004) analysis, the relationship between formal and informal rules relating to position-related consumption is too often competing, where formal rules are weak in curbing extravagant consumption and informal rules tend to circumvent the frugality goal of formal rules. The competing relationship significantly hampers the governance of position-related consumption. When formal rules (such as the enforcement of sanctions against official extravagance) are severe, the effectiveness of formal rules increases, at least in the short term. This may lead to a decline in extravagant consumption. When the enforcement becomes weak, however, official extravagance led by informal rules proliferates again.

Table 8.1 Four types of interaction between formal and informal rules

\begin{tabular}{|l|l|l|l|}
\hline \multicolumn{2}{|c|}{} & \multicolumn{2}{|l|}{ Formal rules } \\
\cline { 3 - 4 } \multicolumn{2}{|c|}{} & Ineffective & Effective \\
\hline \multirow{2}{*}{ Informal rules } & Convergent & Substitutive & Complementary \\
\cline { 2 - 4 } & Divergent & Competing & Accommodating \\
\hline
\end{tabular}

Source: Helmke and Levitsky (2004: 728).

The question, therefore, is how to change their relationship so both types of rules are able to curb lavish position-related consumption. The desirable type of interactions would be complementary, where both formal and informal rules produce similar outcomes and formal rules are effective in curbing official extravagance (Helmke and Levitsky 2004).

26 Interview with a departmental official, Shanghai, October 2013. 
The current anti-extravagance campaign may increase the effectiveness of formal rules, as we can see from its significant short-term effects. Given the outcomes, frugality is apparently the main goal of formal financial management. The CCP has a long tradition of emphasising the need for government officials to exercise frugality in official activities. Frugality is further embodied in various official circulars that regulate and constrain position-related consumption. The frugality standards may contribute to the legitimacy of the CCP. However, those standards for position-related consumption are often too low, ${ }^{27}$ reinforcing informal rules and allowing the formal ones to be ignored.

Convergent outcomes are key to shifting the rules relationship from competing to complementary. According to this research, the proliferation of some informal rules is caused by frugality-oriented formal rules that go too far. Following this logic, accepting the more reasonable aspects of informal rules and reflecting them in the formal rules may be helpful to foster a complementary relationship. However, some of the informal rules are unreasonable and need to be addressed if they are to complement the formal rules. These include a culture of excessive deference to authority and excessive emphasis on personal material gain.

More broadly, the financial management framework and the stronger rules on position-related consumption represent an essential discipline promoting the efficient and effective use of public resources and, in the long run, internalising ethical behaviour and shifting the culture away from personal gain or excessive deference to superiors. With a controloriented fiscal system, the Chinese Government will be able to effectively control position-related consumption. Meanwhile, our research finds that informal rules are persistent and have a competing relationship with formal fiscal rules. While the financial management framework will eliminate some informal rules closely related to official extravagance, it needs to consider the reasonable part of some informal rules and perhaps include them in the framework. That inclusion may help shift the competing relationship to a complementary one.

27 Interview with a senior official of the MoF, Beijing, May 2013; interview with an official in a provincial office, Changsha, March 2014. 


\section{References}

Andrews, M. 2010. 'Good government means different things in different countries'. Governance: An International Journal of Policy, Administration, and Institutions 23(1): 7-35. doi.org/10.1111/j.14680491.2009.01465.x.

Beijing News. 2012. 'How to manage off-budget?' [In Chinese]. The Beijing News, 8 March. Available from: epaper.bjnews.com.cn/html/ 2012-03/08/content_322631.htm?div=0 (accessed 13 May 2015).

Beijing News. 2014. 'Media exposed official banquets'. [In Chinese]. The Beijing News, 14 May. Available from: www.chinanews.com/ gn/2014/05-14/6166667.shtml (accessed 2 June 2015).

Central Discipline Inspection Commission (CDIC). 2013. Notice on Forbidding the Purchase, Printing, and Shipping of Greeting Cards and Related Items using Public Funds. 31 October. Beijing: CDIC.

Central Discipline Inspection Commission (CDIC). 2016a. 'China reported 4785 cases against eight regulations in December 2015'. 12 January. Beijing: CDIC. Available from: www.ccdi.gov.cn/ xwtt/201601/t20160112_72579.html (accessed 29 July 2016).

Central Discipline Inspection Commission (CDIC). 2016b. 'China reported 3215 cases against eight regulations in May 2016'. 21 June. Beijing: CDIC. Available from: www.ccdi.gov.cn/xwtt/201606/ t20160620_80637.html (accessed 29 July 2016).

Central Discipline Inspection Commission (CDIC) and The Mass Line Education Small Leading Group. 2013a. Notice on the Implementation of the Eight Regulations and Strictly Stopping Unhealthy Tendencies, Such As Giving Gifts Bought using Public Funds During Mid-Autumn Day and National Day. 3 September. Beijing: CDIC.

Central Discipline Inspection Commission (CDIC) and The Mass Line Education Small Leading Group. 2013b. Notice on Severely Rectifying the Unhealthy Tendencies of Club Activities in the Party's Mass Line Educational Practice. 22 December. Beijing: CDIC. 
China Economic Times. 2011. '99 per cent of the public questioned the official banquet'. [In Chinese]. China Economic Times, 18 October. Available from: lib.cet.com.cn/paper/szb_con/125324.html (accessed 4 August 2017).

China News Service. 2013. 'The party secretary of Baihe County of Shanxi Province was reported to use high-end vehicles'. [In Chinese]. China News Service, 16 January. Available from: www.chinanews.com/ fz/2013/01-16/4493858.shtml (accessed 13 May 2015).

China Youth Daily. 2012. '87.4 per cent respondents advocated the state to promulgate the standard of official banquets as soon as possible'. [In Chinese]. China Youth Daily, 27 March. Available from: zqb.cyol. com/html/2012-03/27/nw.D110000zgqnb_20120327_1-07.htm (accessed 13 May 2015).

Cope, S. 2000. 'Assessing rational-choice models of budgeting-from budget-maximising to bureau-shaping: A case study of British local government'. Journal of Public Budgeting, Accounting \& Financial Management 12(4): 598-624.

Dittmer, L. 1995. 'Chinese informal politics'. The China Journal 34: 1-34. doi.org/10.2307/2950131.

Dong, L., T. Christensen and M. Painter. 2014. 'Health care reform in China: An analysis of development trends and lack of implementation'. International Public Management Journal 17(4): 493-514. doi.org/10. 1080/10967494.2014.958802.

General Office of the Chinese Communist Party Central Committee (CCPCC) and General Office of the State Council. 1994a. Notice on Abandoning Central-Level Officials' Official Banquets and Accommodation at Domestic Official Visits Over Local Standards. 28 April. Beijing: General Office of the CCPCC.

General Office of the Chinese Communist Party Central Committee (CCPCC) and General Office of the State Council. 1994b. Regulations on the Purchase and Use of Government Vehicles in the Party and Government Organs. 5 September. Beijing: General Office of the CCPCC. 
General Office of the State Council. 2001. Notice on Forwarding the MOF'S Suggestions on Deepening the Reform of Two Lines in Revenue and Expenditure, and Strengthening Fiscal Management. 10 December. Beijing: General Office of the State Council.

General Office of the State Council. 2012. The Major Work Plan of Government Information Disclosure in 2012. [In Chinese]. Beijing: General Office of the State Council. Available from: www.gov.cn/ zwgk/2012-05/17/content_2139583.htm (accessed 10 October 2015).

Gong, T. and H. Xiao. 2017. 'The formation and impact of isomorphic pressures: Extravagant position-related consumption in China'. Governance: An International Journal of Policy, Administration, and Institutions 30(3)(July): 387-405. doi.org/10.1111/gove.12242.

Greenwood, R. and C. R. Hinings. 1996. 'Understanding radical organizational change: Bringing together the old and the new institutionalism'. The Academy of Management Review 21(4): 1022-54.

Guangzhou Daily. 2011. 'Who has borrowed these 16 high-end official vehicles?' [In Chinese]. Guangzhou Daily, 20 August. Available from: opinion.hexun.com/2011-08-20/132643169.html (accessed 4 August 2017).

Guo, Y. 2010. 'Political culture, administrative system reform and anticorruption in China: Taking the official car management institution reform as an example'. Crime Law and Social Change 53(5): 493-508. doi.org/10.1007/s10611-010-9238-5.

Hall, P. A. and R. C. R. Taylor. 1996. 'Political science and the three new institutionalisms'. Political Studies XLIV: 936-57. doi.org/10.1111/ j.1467-9248.1996.tb00343.x.

Helmke, G. and S. Levitsky. 2004. 'Informal institutions and comparative politics: A research agenda'. Perspectives on Politics 2(4): 725-40. doi.org/10.1017/S1537592704040472.

Hindmoor, A. M. 2006. Rational Choice. London: Palgrave Macmillan. doi.org/10.1007/978-0-230-20997-8.

Ho, D. Y. 1976. 'On the concept of face'. American Journal of Sociology 81(4): 867-84. 
Knight, J. 1992. Institutions and Social Conflict. Cambridge: Cambridge University Press. doi.org/10.1017/CBO9780511528170.

Liu, Y. and M. Lin. 2014. 'Formal and informal politics in the budgeting process: A case study of a provincial earmarked fund'. [In Chinese]. Journal of Public Administration 4: 112-32.

Lu, X. B. 2000. 'Booty socialism, bureau-preneurs, and the state in transition: Organizational corruption in China'. Comparative Politics 32(3): 273-94. doi.org/10.2307/422367.

Ma, J. 2009. 'If you can't budget, how can you govern? A case study of China's state capacity'. Public Administration and Development 29: 9-20. doi.org/10.1002/pad.509.

Ma, J. and X. Ni. 2008. 'Toward a clean government in China: Does the budget reform provide a hope?' Crime, Law and Social Change 49(2): 119-38. doi.org/10.1007/s10611-008-9101-0.

Ministry of Finance (MoF). 1998. Regulations of the Fiscal Management of Official Hospitality Items in Administrative Organs and Public Service Units. 14 May. Beijing: MoF.

Ministry of Finance (MoF). 2006. The (Trial) Management Method of Official Trips and Official Meetings at Designated Restaurants by Central Government Departments. November. Beijing: MoF.

Ministry of Finance (MoF). 2011. Fiscal Management Methods of Budget and Final Reports of Government Vehicles in the Party and Government Organs. 4 March. Beijing: MoF.

Ministry of Finance (MoF). 2012. 'On strengthening the fiscal management of three public expenditures and administration cost'. Internal document. Beijing: MoF.

Ministry of Finance (MoF) and Ministry of Foreign Affairs. 2013. Fiscal Management Methods of Temporary Official Overseas Trips. 20 December. Beijing: MoF \& Ministry of Foreign Affairs.

Ministry of Finance (MoF) and National Audit Office (NAO). 2009. Notice on Reducing Expenditures on Three Public Expenditures in the 2009 Fiscal Year. 10 March. Beijing: MoF \& NAO. 
Nanfang Metropolis Daily. 2003. 'To reduce administration cost from the details'. [In Chinese]. Nanfang Metropolis Daily, 10 June. Available from: www.southcn.com/news/gdnews/chuanmei/200306100198.htm (accessed 13 May 2015).

Nanjing Daily. 2013. 'Media reported SOEs' canteens hold banquets for government officials'. [In Chinese]. Nanjing Daily, 27 March. Available from: native.cnr.cn/society/201303/t20130327_51224 0041.shtml (accessed 16 August 2017).

North, D. C. 1990. Institutions, Institutional Change, and Economic Performance. Cambridge: Cambridge University Press. doi.org/ 10.1017/CBO9780511808678.

Peiffer, C. and L. Alvarez. 2015. 'Who will be the "principled-principals"? Perceptions of corruption and willingness to engage in anticorruption activism'. Governance: An International Journal of Policy, Administration, and Institutions 29(3): 351-69. doi.org/10.1111/gove.12172.

People.com. 2005. '700 billion for official banquets'. [In Chinese]. People.com.cn, 27 May. Available from: cppcc.people.com.cn/GB/ 34957/3422068.html (accessed 13 May 2015).

People.com. 2014. 'Wang Qishang's report at the People's Political Consultative Conference has five important messages'. [In Chinese]. People.com.cn, 7 September. Available from: politics.people.com.cn/ n/2014/0907/c1001-25619012.html (accessed 2 June 2015).

People's Daily. 2012. 'Luxurious banquets should be penalised as soon as possible'. [In Chinese]. People's Daily, 31 January. Available from: society.people.com.cn/GB/1062/16973737.html (accessed 13 May 2015).

Persson, A., B. Rothstein and J. Teorell. 2013. 'Why anticorruption reforms fail: Systemic corruption as a collective action problem'. Governance: An International Journal of Policy, Administration, and Institutions 26(3): 449-71. doi.org/10.1111/j.1468-0491.2012.01604.x.

Phoenix. 2013. 'It is sure that position-related consumption is not as high as 900 billion every year'. [In Chinese]. Phoenix, 26 March. Available from: finance.ifeng.com/news/macro/20130326/7822778. shtml (accessed 16 August 2017). 
Study Times. 2004. 'Several starting points of government's administration reform'. [In Chinese]. Study Times. Available from: big5.china.com. cn/chinese/zhuanti/xxsb/1154431.htm (accessed 13 May 2015).

Tsai, W. H. and N. Dean. 2015. 'Lifting the veil of the CCP's mishu system: Unrestricted informal politics within an authoritarian regime'. China Journal 73: 158-85. doi.org/10.1086/679273.

Wangyi. 2013. 'Eight Regulations has no effect because too many government officials come here'. [In Chinese]. Wangyi, 10 December. Available from: news.163.com/13/1210/03/9FN08TGJ0001124J_ all.html\#p1 (accessed 2 June 2015).

Wedeman, A. 2000. 'Budgets, extra-budgets, and small treasuries: Illegal monies and local autonomy in China'. Journal of Contemporary China 9(25): 489-511. doi.org/10.1080/713675947.

Wedeman, A. 2012. Double Paradox: Rapid Growth and Rising Corruption in China. Ithaca, NY: Cornell University Press. doi.org/10.7591/ cornell/9780801450464.001.0001.

Wu, A. M. 2014. Governing Civil Service Pay in China. Copenhagen: Nordic Institute of Asian Studies.

Xinhua. 2014. 'Over 50 star hotels want to downgrade or remove stars'. [In Chinese]. Xinhua, 19 January. Available from: news.xinhuanet. com/politics/2014-01/19/c_119033709.htm (accessed 2 June 2015).

Yin, H. 2011. 'When will three public expenditures not be a hot topic?' [In Chinese]. Nanfengchuang 5: 24-6. 
This text is taken from Value for Money: Budget and financial management reform in the People's Republic of China, Taiwan and Australia, edited by Andrew Podger, Tsai-tsu Su, John Wanna, Hon S. Chan and Meili Niu, published 2018 by ANU Press, The Australian National University, Canberra, Australia. 